Семенова Инна Владимировна

аспирант кафедры социологии

Российского университета дружбы народов

\section{СПЕЦИФИКА ИСПОЛЬЗОВАНИЯ МОДЕЛЕЙ КОМПЕТЕНЦИЙ НА ГОСУДАРСТВЕННОЙ СЛУЖБЕ}

Аннотация:

Государственная служба является основным ин струментом административного управления и связующим звеном между государством и обществом. Поддержание связей между данными элементами и эфффективная работа госаппарата во многом определяются государственными служащими и их подходом к своей деятельности. Обеспечение поступления на госслужбу профессиональных сотрудников невозможно без разработки, внедрения и поддержания системы квалификационных нормативов и продуктивных моделей отбора, включающих ориентированные на цели и задачи государственного органа требования к образованию, навыкам и знаниям, а также профессиональным и личностным качествам (компетенциям). В условиях административных реформ в России были приняты законодательные акты и поправки, регламентирующие подобные требования. Для всех категорий должностей определены такие ключевые компетенции, как cтратегическое мышление, коммуникабельность, умение планировать и ориентироваться в разных ситуациях. В статье обозначены навыки, обязательные для руководящих должностей, и поведенческие индикаторы, отображающие специфику каждой компетенции. Кроме того, исследованы методологические основания для формирования моделей и эмпирические методы оценки профессиональных компетенций государственных служащих.

Ключевые слова:

компетенции, модели компетенций, государственные служащие, государственная служба, профессиональная компетентность, профессиональные качества, ценностные ориентации, управление персоналом.
Semenova Inna Vladimirovna

PhD student, Social Science Department, Peoples' Friendship University of Russia

\section{THE SPECIFIC NATURE OF COMPETENCY MODELS IN PUBLIC SERVICE}

\begin{abstract}
Summary:
The public service is the main administrative tool that links government and society. The relationships between these elements and effective public administration depend on professional competencies of public officers and their approach to the activities. The new qualified public servants can enter on duty in terms of the development and implementation of qualification requirements system and effective selection models that include requirements for education, skills, knowledge, professional and personal strengths (competencies) focused on the goals and objectives of the government. In the context of Russian administrative reforms, new legislative instruments and amendments regulating such requirements were adopted. These reforms defined such core competencies as strategic thinking, sociability, planning, and multitasking for all categories of public employees. The study identifies the range of skills required for leadership positions and behavioral indicators demonstrating the specific nature of each competence. Besides, the author examines the methodological basis for the development of competency models and empirical methods for assessing the professional skills of public officers.
\end{abstract}

Keywords: competencies, competency models, public officers, public service, professional competence, professional strengths, values, personnel management.

Несколько последних десятилетий структура государственной службы РФ находится на стадии реорганизации. Утвержденная в августе 2001 г. административная ресорма стала отправной точкой для определения направлений перемен в государственных и законодательных органах. Одним из таких векторов являются разработка государственных стандартов и совершенствование системы подготовки и переподготовки госслужащих.

Федеральным законом от 27.05.2003 г. № 58-Ф3 «О системе государственной службы Российской Федерации» были определены основные принципы построения и функционирования системы госслужбы. Согласно им государственная деятельность предполагает высокую квалификацию сотрудников и требует от них определенных навыков, опыта и компетенций.

Компетенции государственных служащих можно разделить на три уровня.

1. Гражданский уровень компетенций - регламентированные Конституцией права и обязанности, контролируемые моральными принципами и нормами общества. Наличие данного уровня обязательно для всех сотрудников государственных органов, поскольку он является базовым.

2. Под профессиональным уровнем компетенций понимается совокупность знаний, навыков и ценностных ориентаций, которые требуются для осуществления трудовой деятельности в выбранной сфрере. К ним относятся профессиональный опыт, полученные в процессе обучения знания и личный опыт индивида. 
3. Политический уровень компетенций относится скорее к руководящим и ведущим должностям. Такой сотрудник должен обладать критическим взглядом на ситуацию, постоянно развивать свои профессиональные навыки [1]. Высший уровень компетенции напрямую связан с первыми двумя [2].

В условиях реформирования государственной службы особое значение отводится разработке моделей компетенций, определяющих требования к профессиональному уровню компетенций (опыта, знаний, навыков), а также к установлению актуальных критериев оценки показателей эффективности сотрудников. В соответствии с профессиональными стандартами госслужащих РФ под моделью профессиональных умений понимается набор компетенций и их характеристик, сформированный на основе должностных обязанностей гражданского служащего [3].

Российская модель компетенций для госслужащих определяет две целевые группы - гражданские служащие и ведущие специалисты (руководители). Для всех должностей регламент включает следующие требования: 1) умение мыслить стратегически (системно); 2) умение планировать, рационально использовать служебное время и достигать результата; 3) коммуникативные навыки; 4) умение управлять изменениями (таблица 1) [4].

\section{Таблица 1 - Базовые компетенции для государственных служащих РФ}

\begin{tabular}{|c|c|c|}
\hline $\begin{array}{c}\text { Перечень компетенций } \\
\text { (профессиональных } \\
\text { и личностных качеств) }\end{array}$ & $\begin{array}{c}\text { Характеристики } \\
\text { компетенций } \\
\text { (умения) }\end{array}$ & Поведенческие индикаторы \\
\hline $\begin{array}{l}1.1 \quad \text { Стратегическое } \\
\text { мышление }\end{array}$ & $\begin{array}{l}\text { Умение мыслить } \\
\text { стратегически } \\
\text { (системно) }\end{array}$ & $\begin{array}{l}\text { Выявление пробелов в информации, поиск возможных источ- } \\
\text { ников и формулировка точных вопросов для ее получения } \\
\text { Определение взаимосвязи частей проблемы, поиск при- } \\
\text { чины ее возникновения } \\
\text { Анализ ситуации в широком контексте, с учетом влияния } \\
\text { максимального количества фракторов } \\
\text { Точный прогноз развития событий и их оценка с точки зрения } \\
\text { того, как они могут отразиться на других (людях, организа- } \\
\text { циях, регионах), в том числе в долгосрочной перспективе } \\
\text { Предложение вариантов решений, направленных на } \\
\text { предотвращение потенциальных проблем и использова- } \\
\text { ние будущих возможностей } \\
\text { Ориентация на стратегические цели государственного органа }\end{array}$ \\
\hline $\begin{array}{l}\text { 1.2. Командное взаимо- } \\
\text { действие }\end{array}$ & $\begin{array}{l}\text { Коммуникатив- } \\
\text { ные навыки }\end{array}$ & $\begin{array}{l}\text { Общение в уважительной и доброжелательной манере } \\
\text { Установление и поддержание долгосрочных партнерских } \\
\text { отношений с людьми внутри организации и вне ее, расши- } \\
\text { рение круга контактов } \\
\text { Учет в своих действиях потребностей других людей, опре-- } \\
\text { деление взаимовыгодных решений, проявление готовно- } \\
\text { сти идти на компромисс } \\
\text { Четкое и ясное выражение своей точки зрения, последо- } \\
\text { вательность и логичность изложения позиции в нужных } \\
\text { для собеседника объеме и формате } \\
\text { Проявление уверенности в общении с разными людьми } \\
\text { Аргументированность собственной точки зрения } \\
\text { Оказание влияния и умение найти поддержку у других для } \\
\text { продвижения идей, решений, проектов }\end{array}$ \\
\hline $\begin{array}{l}1.3 \text { Персональная эф- } \\
\text { фективность }\end{array}$ & $\begin{array}{l}\text { Умение планиро- } \\
\text { вать, рацио- } \\
\text { нально использо- } \\
\text { вать служебное } \\
\text { время и дости- } \\
\text { гать результата }\end{array}$ & $\begin{array}{l}\text { Выполнение задач в установленные сроки } \\
\text { Настойчивость в работе } \\
\text { Обеспечение контроля над процессами и людьми }\end{array}$ \\
\hline $\begin{array}{l}\text { 1.4. Гибкость и готов- } \\
\text { ность к изменениям }\end{array}$ & $\begin{array}{l}\text { Умение управ- } \\
\text { лять изменени- } \\
\text { ями }\end{array}$ & $\begin{array}{l}\text { Предложение новых способов работы для повышения эфр- } \\
\text { фективности исполнения должностных обязанностей } \\
\text { Рассмотрение идей и предложений других по повышению } \\
\text { эффрективности исполнения должностных обязанностей } \\
\text { Умение разъяснять другим необходимость изменений } \\
\text { Многозадачность } \\
\text { Поддерживание высокого качества работы при необходи- } \\
\text { мости выполнения нескольких задач } \\
\text { Способность быстро ориентироваться в решении про- } \\
\text { блем, переходя от реализации одной задачи к выполне- } \\
\text { нию другой }\end{array}$ \\
\hline
\end{tabular}


Для руководящих должностей дополнительно предусмотрены следующие требования: 1) умение руководить подчиненными, эффективно планировать время, организовывать работу и контролировать ее выполнение; 2) навык оперативно принимать и реализовывать управленческие решения по поставленным задачам.

В рамках обеспечения кадрового резерва государственных служащих в проекте «Лидеры России» разработчиками обозначены следующие компетенции, которыми должен обладать успешный лидер: 1) лидерство - готовность принимать на себя ответственность за результаты деятельности других; 2) нацеленность на результат - амбициозность и целеустремленность; 3) стратегическое мышление - навык системно анализировать информацию; 4) умение работать в команде - готовность к сотрудничеству и работе сообща с другими для достижения общего результата; 5) коммуникация и влияние - умение выстраивать контакт, четко излагать мысли; 6) внедрение изменений - конструктивное отношение к нововведениям; 7) инновационность способность предлагать новые нестандартные идеи; 8) социальная ответственность - ориентация на интересы общества.

Наиболее распространенный способ формирования модели - это оценка и составление списка необходимых компетенций для той или иной категории должностей или отдельно взятой позиции. Например, характеристика эффрективности мышления, необходимая при работе в младшей должности, меняется от ответственного до стратегического мышления для начальника. Такая модель компетенции была предложена для оценки результативности деятельности государственных служащих Владимирской области [5, с. 193]. Авторы отмечают, что компетенции сотрудников можно выстроить по шкале от базовых, соответствующих начальным должностям, до лидерских, отвечающих руководящим позициям. Здесь следует говорить о накопительном эффекте, когда высокий уровень компетенции складывается из основного набора и дополнительных умений.

С.М. Спенсер и Л.М. Спенсер выдвинули способ формирования модели компетенций на основе кластеров, т. е. собранных в группы по схожим признакам и имеющих определенный уровень скрытых социальных мотивов и поверхностных типов поведения [6]. Данный подход послужил методологической базой при формировании для российских органов государственной службы новых моделей компетенций. Например, О.В. Юрьева и Л.А. Бурганова предложили несколько кластеров профессиональных компетенций, отражающих личные качества и поведенческие шаблоны, необходимые для достижения поставленных целей. В число таких кластеров входят когнитивные, инновационные, инициативные, коммуникативные, лидерские, сервисные и стратегические компетенции [7]. Максимальное внимание авторы уделяют стратегическому кластеру, подчеркивая важность достижения стратегических целей государственных структур, отражающих главный смысл деятельности организации и перспективы развития. Сотрудник, обладающий стратегическими компетенциями, - это человек, умеющий правильно выстраивать коммуникационный процесс, вовлеченный во все изменения, затрагивающие сферу его деятельности, преданный работе.

Также часто используется подход, позволяющий оценить потенциал карьерного роста и создать модель компетенций на основе должностных обязанностей служащего [8]. В данном случае анализируются моральные качества человека, отражающие нравственную составляющую. При этом модели компетенции формируются исходя из психологических особенностей, дающих возможность определить ключевые фракторы эффективности сотрудника, относящиеся к структуре личности [9].

Система управления персоналом, основанная на модели компетенций, состоит из механизмов конкурсного отбора сотрудников, оценки и аттестации, обучения персонала, развития необходимых навыков для эффективной трудовой деятельности. Данная система может дополняться механизмом наставничества на работе или возможностью формирования кадрового резерва и ротации.

В соответствии с выбранным подходом к созданию модели компетенций определяется метод оценки прфессионализма государственных служащих: 1) анкетирование; 2) индивидуальное собеседование (структурированное или ролевое интервью); 3) групповая дискуссия (кооперативная групповая дискуссия, конкурентная групповая дискуссия, дискуссия с ролью лидера); 4) реферат либо творческие упражнения; 5) тестирование [10, с. 53]. Оценка кандидатов на открытую вакансию происходит по четырем выделенным категориям государственных служащих: «руководители», «специалисты», «помощники, советники» и «обеспечивающие специалисты».

Если говорить в целом об использовании системы профессиональных компетенций в государственной службе, следует отметить, что именно этот метод подбора и оценки персонала широко распространен как в иностранных организациях, так и в российских. Модель компетенций определяется исходя из требований к должности, трудовым обязанностям и специфики деятельности государственного органа. К основным умениям в должностном регламенте, одобренном Минтруда РФ, относят стратегическое мышление, командное взаимодействие, персональную 
эфффективность и готовность к изменениям в трудовой среде. Однако недостаточная конкретизация в нормах и правилах служебного поведения не позволяет руководствоваться ими в повседневной деятельности, а обладание необходимыми компетенциями и принятие внешних правовых норм являются неотъемлемыми условиями развития института государственной службы.

\section{Ссылки:}

1. Лобанов В.В. Управление высшим административным персоналом (опыт Голландии и США) // Проблемы теории и практики управления. 2000. № 2. С. 72-74.

2. Налбандян Д. Профессионалы в местных органах управления // Профессионализм управленческих кадров. М., 1994. C. 60-61.

3. Методический инструментарий по установлению квалификационных требований для замещения должностей государственной гражданской службы. Версия 3.2 [Электронный ресурс] : утв. Министерством труда и социальной защиты РФ. С. 17. Доступ из справ.-правовой системы «Гарант».

4. Там же.

5. Лапыгин Ю.Н., Ерашова О.В. Модели компетенций государственных гражданских служащих // Современная экономика: Проблемы, тенденции, перспективы. 2013. № 9. С. 189-208.

6. Spenser L., Spenser S. Competence at work. N. Y., 1993.

7. Юрьева О.В., Бурганова Л.А. Модель стратегической компетенции государственных гражданских служащих // Вестник экономики, права и социологии. 2017. № 1. С. 193-195.

8. Методический инструментарий ...

9. Пузанова Ж.В., Корнаухова Ю.С. Компетентностный подход в образовательной и управленческой практике: модели компетенций // Вестник Российского университета дружбы народов. Сер.: Социология. 2014. № 1. С. 83-90.

10. Турняк К.В., Шакина М.А. Модели профессиональных компетенций работников государственного и муниципального управления в условиях нового государственного менеджмента: отечественный и зарубежный опыт // Ars Administrandi. 2012. № 4. C. 41-55.

\section{References:}

Lapygin, YuN \& Erashova, OV 2013, 'Competency models of public servants', Sovremennaya ekonomika: Problemy, tendentsii, perspektivy, No. 9, pp. 189-208, (in Russian).

Lobanov, VV 2000, 'Management of higher administrative personnel (experience of the Netherlands and the USA)', Problemy teorii i praktiki upravleniya, No. 2, pp. 72-74, (in Russian).

Nalbandyan, D 1994, 'Professionals in local government bodies', Professionalizm upravlencheskikh kadrov, pp. 60-61, (in Russian).

Puzanova, ZhV \& Kornaukhova, YuS 2014, 'Competency-based approach in educational and management practice: competency models', Vestnik Rossiyskogo universiteta druzhby narodov. Ser.: Sotsiologiya, No. 1, pp. 83-90, (in Russian). Spenser, L \& Spenser, S 1993, Competence at work, New York.

Turnyak, KV \& Shakina, MA 2012, 'Professional competency model of state and municipal government employees under the new state management: Russian and international practices', Ars Administrandi, No. 4, pp. 41-55, (in Russian).

Yuryeva, OV \& Burganova, LA 2017, 'Strategic competency model of public servants', Vestnik ekonomiki, prava i sotsiologii,

No. 1, pp. 193-195, (in Russian). 